\title{
ARTICLE
}

\section{Substitution or Complementation: The Relationship between School Education and Shadow Education}

\author{
Jiali Li \\ Shanghai Normal University, Shanghai 200234, China
}

\begin{abstract}
In order to explore the relationship between school education and shadow education, this study applied two-level Bernoulli Model to estimate the school-level determinants of private tutoring by analyzing the data of PISA 2015 of four regions of China (Beijing, Shanghai, Jiangsu, and Guangdong). The results indicated that: (1) the four regions have large scale of private tutoring ranging from $58.7 \%$ to $74.0 \%$ for science, mathematics, and reading; (2) the participation rate of private tutoring in villages is much higher than that in cities; (3) the quality of school teachers significantly negatively affects the likelihood for receiving tutoring. Shadow education plays both substitutional and complementary roles for school education, and the growth of shadow education is in accompany with the low quality of school education in rural areas but with high quality of school education in urban areas. Instead of increasing Education resources and improving infrastructure, increasing teacher quality will reduce the participation probability of private tutoring.
\end{abstract}

Best Evid Chin Edu 2019; 4(1):411-424.

Doi: 10.15354/bece.20.ar015.

Keywords: Shadow Education; Private Tutoring; Education Quality; Two-Level Bernoulli Model

Correspondence to: Jiali Li, Research Institute for International and Comparative Education, Shanghai Normal University, Shanghai 200234, China. E-mail: eduhappycharlie@163.com.

Funding: The National Natural Science Foundation project "Family Capital, Shadow Education and Social Reproduction" (NSFC, 71774112).

Conflict of Interests: None. 


\section{Introduction}

HADOW education, which is also called private tutoring, has been becoming of great popularity in China, especially in developed regions, such as Beijing, Shanghai, and Guangdong. In 2014, 48.9\%-58.1\% of elementary students and $66.8 \%-74.4 \%$ of middle school students received private tutoring in Shanghai (Zhang \& Bray, 2016). In Beijing, $60.5 \%$ of elementary students and $58.4 \%$ of middle school students attended private tutoring in 2015 ( $\mathrm{Lu}, 2016$ ). Early in 2012, the participation rate of tutoring in Guangzhou ranged from $51.7 \%$ to $73.1 \%$. With the global expansion of private tutoring, a growing number of studies explored the factors underlying the demand for private tutoring. Macro-factors, such as culture, education competition, and development of economic, have significant impact on the demand of tutoring. For example, Confucianism, one of the cultural factors, places value on education and instills a hard work ethic on children, is often mentioned as the "soil" (driver) for private tutoring (Zhu, 2013). The high-stakes examination exhibits great demand for tutoring as well as other supplementary learning activities. The growing of family income increases the chance to purchase tutoring service for their children, and institutionalization of public schooling stimulates parents and students to seek extra learning activities (Park et al., 2016). Family background, gender, and ethnic minorities are also strongly associated with the development of tutoring. However, before embarking on the factors underlying the development of tutoring, it's necessary to explore the definition and nature of shadow education. The term of shadow education refers to various type of tutoring, and the metaphor of "shadow" highlights the relationship between private tutoring and regular schooling. Private tutoring exists only because of the existence of regular education though; its shape and size change following that of the regular education; the curriculum in the "shadow" ones mimics the curriculum inside the regular schools and changes accordingly (Bray, 1999). The relationship means that the development of private tutoring can be explained by the public education, and it also reflects the development of education quality and equity.

Some debates exist about the relationship between regular education and shadow education. First, when the mainstream education system is perceived to be of poor quality, parents and students may be motivated to seek extra forms of academic learning in private market, so some studies have attempted to find a link between quality of public schooling and demand for private tutoring. Popa and Acedo (2006) noted that the backdrop of reduced funding for public schooling, increasingly poor population and teachers' low salary were the reasons for the increasing of private tutoring in Eastern Europe. In Korea, students from schools with higher student-teacher ratios tended to spend more time in private tutoring (Kim \& Lee, 2010). Similarly, Dang (2007) found that as teacher quality increased in Vietnam, the amount of money families spent on private tutoring decreased. This assumption postulates that the inadequacies of public education stimulate the high demand for private tutoring. Given the limitations of public schooling in meeting individualized needs for learning, private tutoring may play a role as a substitutional institution. However, institutional perspective on educational devel- 
opment offers a counter-explanation for the relationship between schooling quality and the demand for shadow education. Baker and LeTendre (2005) argued that growing demand for private tutoring reflected the institutionalization of public schooling. As the demand for educational opportunity and quality increases across social classes within and between countries, middle-class parents begin to seek private sources of additional learning for their children, because it becomes more difficult for them to influence regular schooling processes to maintain their children's advantage. For example, during the years of 2003 to 2010, the participation rate of private tutoring was much higher in urban areas and in high-quality schools in China (Xue \& Ding, 2009; Tseng, et al., 2010). From this perspective, growing demand for shadow education is complementary to the regular education, which is supported by the theory of Supply and Demand as well as the theory of Effectively Maintained Inequality (EMI).

Based on the microeconomic theory of Supply and Demand, the demand for private tutoring depends on the quantity and quality of public education. When the quantity of public education cannot meet the demand of all the families, the families with high demand will take advantage of family capital to obtain more and better public education. While, when the supply of public schooling increases, the families with low demand can also receive regular education, the high-demand families will seek out-ofschool activities to keep their advantage to access to higher education (Dang \& Rogers, 2008). Xue (2015) employed EMI to indicate the relationship between regular education and shadow education, and they mentioned that when compulsory education basically universal has not been achieved, the core of education competitive is the access chance to regular education for students from different social classes. When the compulsory education basically universal is completed, the core of education competitive is the quality of school education. When the government takes measures to decrease the gap of educational quality between urban and rural areas, and between different schools, the core of education competitive will shift from educational quality to shadow education.

Thus, more empirical study is in need to verify whether the demand for shadow education is driven by the quality of public education. Is growing demand for shadow education due to the poor quality of school education, being substitutional to regular education, or due to the high quality of public schooling, being supplementary to regular education? Although previous studies indicated that students from better schools are more likely to receive private tutoring (Xue, 2009; Tseng et al., 2006), the dataset of these two studies were collected from urban cities in 2004 and 2009, when the compulsory education has not been completed. In order to explore the relationship between shadow education and regular school education, this study applies two-level Bernoulli Model to estimate the school-level determinants of private tutoring by analyzing the data of PISA 2015 of four regions of China including Beijing, Shanghai, Jiangsu, and Guangdong.

\section{Methods}




\section{Sample}

This study uses the data of the PISA 2015 of four regions (Beijing-Shanghai-JiangsuGuangdong). PISA program has been sponsored by the Organization for Economic Cooperation and Development (OECD) every three years since 2000. It applied two-stage stratified sampling to randomly select 9,841 students of 286 schools in the four regions, and the weighted sample covered $96 \%$ of all the 15-year-old students. Apart from the international assessment of mathematics, reading, and science, and the survey also collected extensive background information of teachers and schools.

\section{Variables}

Previous empirical studies have found that students' family background, demographic and academic ability are related to their participation in private tutoring (Bray, et al., 2014; Choi \& Park, 2016; Li \& Hu, 2017), and this study will control these factors to estimate the impact of school-level factors on students' probability of receiving private tutoring.

Education quality will be measured from three dimensions, i.e., education input, education process and education output. Items measuring education input and education process are usually taken as independent variables, while items measuring education output are used to be dependent variables (Hanushek, 1986). Education input variables include education resources, quality of teachers, and quality of students (Shavelson \& Baxter, 1992). Education resources include a questionnaire with 8 items about school resources, the school principals' perceptions of potential factors hindering the provision of instruction at school. The quality of teachers includes the index on staff shortage, which is derived from 4 items, as well as the proportion of teachers with bachelor or master degree. The quality of students is measured by the average ESCS of students' family background. Education equity, which is called quality of education opportunity, emphasizes that students from different ESCS background should have equal access to education (Coleman, 1966). In China, educational equity is also called "education balance", measured by three disparities, i.e., urban-rural disparity, region disparity and individual disparity (Wu, 2010). This study will analyze the relationship between education quality and shadow education by exploring the urban-rural disparity and schooling disparity in receiving tutoring. For a more detailed description of the variables, refer to Table 1.

\section{Data Analysis}

A two-level Bernoulli model that is also called two-level hierarchical generalized linear model (HGLM) was used to estimate the effects of various student- and school-level variables on students' participation in private tutoring. The two-level Bernoulli model was used because student-level variables nested in the school-level, and the dependent variable is a dummy variable indicating whether or not the student participates in private tutoring. The level-1 and level-2 models are as follows: 
Level-1 model:

$$
Y_{i j}=\log \left(\frac{P_{i j}}{1-p_{i j}}\right)=\beta_{0 j}+\sum \beta_{i j} X_{i}+\varepsilon_{i j}
$$

Level-2 model:

$$
\begin{gathered}
\beta_{0 j}=\gamma_{00}+\sum \gamma_{0 s} K_{j}+\mu_{0 j} \\
\beta_{i j}=\gamma_{i 0}
\end{gathered}
$$

where $X_{i}$ is a vector of level-1 control variables, $\beta_{i j}$ refers to regression coefficient of level-1, $\varepsilon_{\mathrm{ij}}$ is the error term for level-1; $\mathrm{K}_{\mathrm{j}}$ is a vector of level-2 control variables, $\gamma_{0 \mathrm{~s}}$ refers to regression coefficient of level-2, $\mu_{0 j}$ is the error term for level-2. (Only intercept term is random, and the coefficients of level-2 are fixed)

\section{Results}

\section{Descriptive Statistics}

Table 2 shows the results of the descriptive statistics. In general, the participation rate of science, mathematics and reading tutoring is $58.7 \%, 74 \%$, and $63.4 \%$, respectively in the four regions. The academic achievement of students from cities, high quality schools and high ESCS families is better than that of the students from villages, low quality schools, and low ESCS families. But the scale of tutoring is larger in villages, low quality schools, and low ESCS families than in their counterparts. Comparing with the high school students, middle school students received more tutoring, but the academic achievement of high school students is much higher than middle school students. There are significant intergroup disparities in the distribution of participation in private tutoring and students' performance regarding urban-rural areas, institutional, family backgrounds, and individual ability. The results, that the participation rate of private tutoring in villages is much higher than that in towns and cities, and the lowest ESCS families have the highest participation rates, are totally different from the results of Xue's report, from which the participation rate of tutoring is much higher in undeveloped county-level towns, poor quality schools than that in capital cities, high quality schools in 2009. The results based on PISA2015 indicated that the prevalence of tutoring might gradually transfer from urban areas to rural areas, and the tutoring market has also begun to attract students from poor families.

Due to the availability of data, most of previous studies mainly focused on the prevalence of tutoring, as well as the determinants and impacts of tutoring, few studies explored what kind of tutors the students preferred. Our study estimates the selection and distribution of tutors to explain the relationship between school education and shadow education. Table 3 indicates that regular teachers are most frequently used tutors, with over $50 \%$ of students indicated tutoring by their own teachers. Around 29\%- 
Table 1. Variable Descriptions.

\begin{tabular}{|c|c|}
\hline Variable & Variable Descriptions \\
\hline \multicolumn{2}{|c|}{ Dependent Variable } \\
\hline Private Tutoring & $0=$ no, $1=y e s ;$ three subjects: science, mathematics, reading. \\
\hline \multicolumn{2}{|c|}{ Independent Variables } \\
\hline \multicolumn{2}{|l|}{ Student-Level } \\
\hline Female & $0=$ male, 1 =female \\
\hline Study Program & $0=$ middle school, $1=$ high school. \\
\hline Students' Ability & The mean score of science, mathematics, and reading. \\
\hline $\begin{array}{l}\text { Students' Educa- } \\
\text { tional Expectation }\end{array}$ & $\begin{array}{l}1=\text { middle school, } 2=\text { two-year high school, } 3=\text { high school, } 4=\text { vocational high } \\
\text { school, } 5=\text { three-year college, } 6=\text { four-year college and above. }\end{array}$ \\
\hline $\begin{array}{l}\text { Family Economic, } \\
\text { Social And Cul- } \\
\text { tural Status } \\
\text { (ESCS) }\end{array}$ & $\begin{array}{l}\text { Parents' highest education level, parents' highest occupation status, and home } \\
\text { possessions compute the index of family ESCS. More the scores are, higher the } \\
\text { family ESCS status is. }\end{array}$ \\
\hline \multicolumn{2}{|l|}{ School-Level } \\
\hline School Location & $\begin{array}{l}\text { A village, hamlet or rural area (fewer than } 3000 \text { people)(reference group), a small } \\
\text { town ( } 3,000 \text { to about } 15,000 \text { people), a town ( } 15,000 \text { to about } 100,000 \text { people),a } \\
\text { city }(100,000 \text { to about } 1,000,000 \text { people), a large city (with over } 1,000,000 \text { people). }\end{array}$ \\
\hline $\begin{array}{l}\text { Quality of } \\
\text { Education } \\
\text { Resources }\end{array}$ & $\begin{array}{l}\text { The shortage of school Education resources is scaled using four items: a lack of } \\
\text { educational material (e.g. textbooks, IT equipment, library or laboratory material), } \\
\text { inadequate or poor quality educational material (e.g. textbooks, IT equipment, li- } \\
\text { brary or laboratory material), a lack of physical infrastructure (e.g. building, } \\
\text { grounds, heating/cooling, lighting and acoustic systems), inadequate or poor quality } \\
\text { physical infrastructure (e.g. building, grounds, heating/cooling, lighting and acoustic } \\
\text { systems). More the scores are, lower quality of the schooling resources is. }\end{array}$ \\
\hline $\begin{array}{l}\text { Quality of } \\
\text { Teachers }\end{array}$ & $\begin{array}{l}\text { (1) Staff shortage is derived from four items: A lack of teaching staff, inadequate or } \\
\text { poorly qualified teaching staff, and a lack of assisting staff, inadequate or poorly } \\
\text { qualified assisting staff. More the scores are, lower quality of teachers is. } \\
\text { (2) The proportion of teachers with bachelor qualification (PROAT5AB), the propor- } \\
\text { tion of teachers with master qualification (PROAT5AM), the proportion of fully certi- } \\
\text { fied teachers (PROATCE). }\end{array}$ \\
\hline $\begin{array}{l}\text { Quality of } \\
\text { Students }\end{array}$ & $\begin{array}{l}\text { The mean scores of students' family ESCS aggregated in school level. More the } \\
\text { scores are, higher the family ESCS status of school is. }\end{array}$ \\
\hline
\end{tabular}

$40 \%$ of the students choose specialized tutors working for a business or organization. Non-specialized tutors are the least used. The academic achievement of the students choosing specialized tutors is the highest, whereas the students choosing nonspecialized tutors are the lowest.

To explain why the participation rate of tutoring in village and small town is much higher than that of in city, we explored whether the choice of tutors varies across the groups of students. The choice of tutors varies significantly across students' schooland family- backgrounds. Regular teachers are mostly used tutors for the students from village schools, but low quality schools with smallest number of teachers with master qualification and lowest ESCS families. Although special tutors working for a business 


\section{Table 2. The Distribution of Private Tutoring in the Four Regions.}

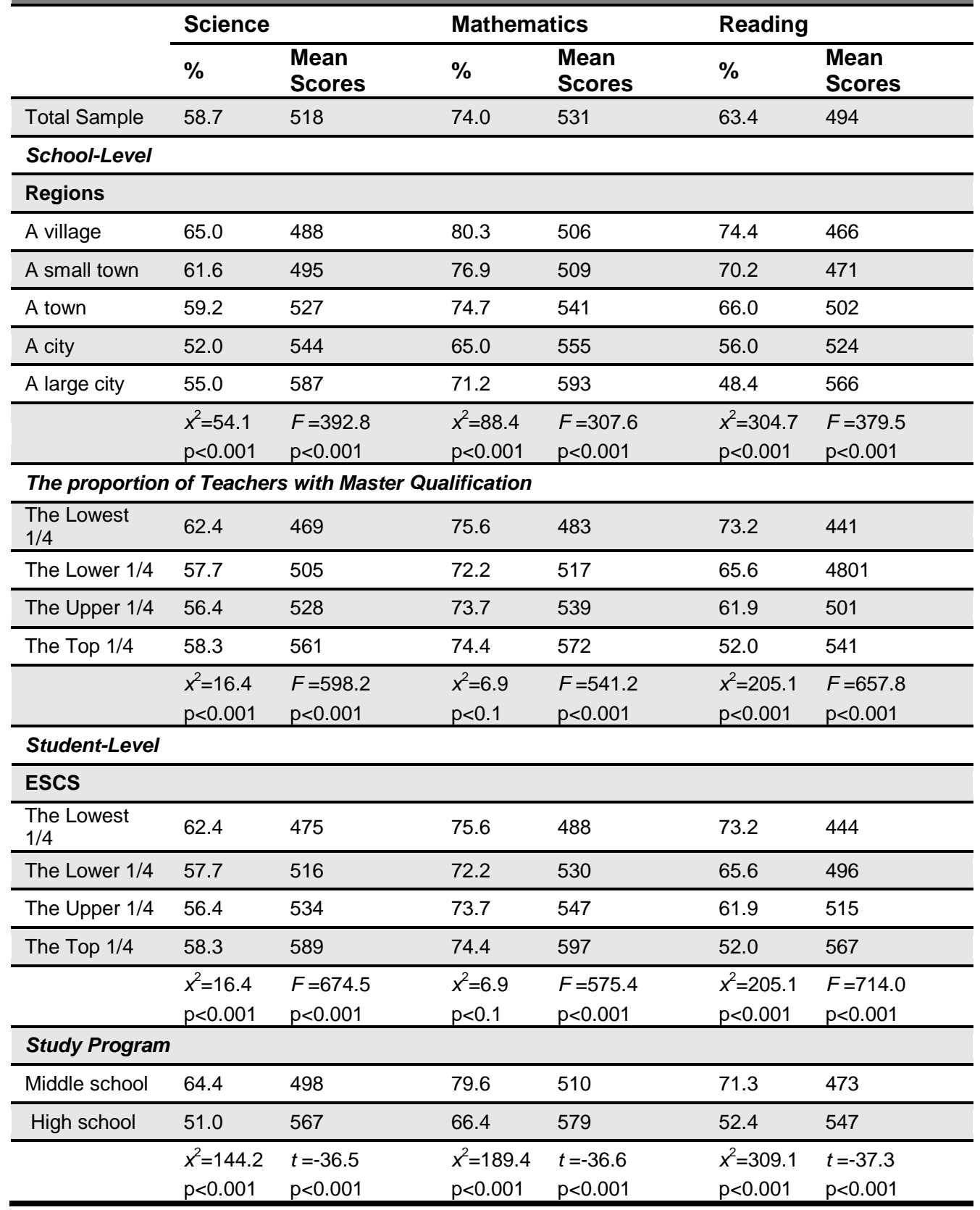

are the mostly used for the students from lager cities, high quality schools with largest number of teachers with master qualification and highest ESCS families. Although more and more disadvantage students start to access to tutoring market, the quality of tutoring they receive might be not as good as the advantage students. We can also spec- 


\begin{tabular}{|c|c|c|c|c|c|c|}
\hline & \multicolumn{2}{|c|}{ Science } & \multicolumn{2}{|c|}{ Mathematics } & \multicolumn{2}{|c|}{ Reading } \\
\hline & $\%$ & $\begin{array}{l}\text { Mean } \\
\text { Scores }\end{array}$ & $\%$ & $\begin{array}{l}\text { Mean } \\
\text { Scores }\end{array}$ & $\%$ & $\begin{array}{l}\text { Mean } \\
\text { Scores }\end{array}$ \\
\hline $\begin{array}{l}\text { 1. One of My Regular Teach- } \\
\text { ers }\end{array}$ & 53.4 & 496 & 52.3 & 510 & 56.4 & 468 \\
\hline $\begin{array}{l}\text { 2. Other Regular Teachers in } \\
\text { School }\end{array}$ & 36.7 & 505 & 33.2 & 515 & 29.6 & 479 \\
\hline $\begin{array}{l}\text { 3. Specialized Tutors Works } \\
\text { for A Business or Organiza- } \\
\text { tion. }\end{array}$ & 39.9 & 510 & 34.4 & 524 & 29.6 & 486 \\
\hline 4. Non-Specialized Tutors & 16.2 & 470 & 13.6 & 488 & 14.4 & 439 \\
\hline $\begin{array}{l}\text { Note: this is a multiple-choice } \\
\text { courses; } 2 \text {. The teacher regula } \\
\text { regular school courses; } 3 \text {. The } \\
\text { tional instruction; } 4 \text {. The teach }\end{array}$ & $\begin{array}{l}\text { stio } \\
\text { tea } \\
\text { che } \\
\text { no }\end{array}$ & he $t$ & $e$ & regular & $\begin{array}{l}\text { s in th } \\
\text { each } \\
\text { speci } \\
\text { nt). }\end{array}$ & $\begin{array}{l}\text { year's s } \\
n \text { any of } \\
\text { zed in ac }\end{array}$ \\
\hline
\end{tabular}

\section{Table 4. Type of Tutors Used Across Groups of Students.}

\begin{tabular}{|c|c|c|c|c|c|c|c|c|c|c|c|c|}
\hline & \multicolumn{4}{|c|}{ Science } & \multicolumn{4}{|c|}{ Mathematics } & \multicolumn{4}{|c|}{ Reading } \\
\hline & 1 & 2 & 3 & 4 & 1 & 2 & 3 & 4 & 1 & 2 & 3 & 4 \\
\hline \multicolumn{13}{|l|}{ Region } \\
\hline A Village & 58.9 & 37.0 & 41.5 & 19.3 & 55.1 & 32.2 & 37.0 & 17.3 & 57.9 & 30.3 & 33.2 & 15.6 \\
\hline $\begin{array}{l}\text { A Small } \\
\text { Town }\end{array}$ & 61.2 & 36.9 & 37.5 & 17.8 & 59.1 & 33.3 & 31.9 & 14.7 & 62.5 & 30.8 & 29.6 & 16.1 \\
\hline A Town & 56.6 & 36.5 & 34.6 & 16.2 & 58.2 & 31.2 & 29.9 & 13.2 & 59.3 & 27.9 & 25.6 & 14.2 \\
\hline A City & 51.6 & 35.1 & 36.6 & 15.9 & 53.0 & 31.6 & 31.3 & 14.2 & 53.5 & 27.4 & 26.6 & 14.8 \\
\hline $\begin{array}{l}\text { A Large } \\
\text { City }\end{array}$ & 36.1 & 37.1 & 48.7 & 11.8 & 34.7 & 36.0 & 42.7 & 9.4 & 40.9 & 29.0 & 34.0 & 9.1 \\
\hline \multicolumn{13}{|c|}{ The Proportion of Teachers with Master Qualification } \\
\hline Low $1 / 3$ & 62.3 & 38.6 & 37.5 & 20.3 & 61.7 & 32.7 & 31.1 & 17.1 & 61.9 & 31.6 & 29.7 & 16.8 \\
\hline $\begin{array}{l}\text { Middle } \\
1 / 3 \\
\end{array}$ & 52.8 & 35.9 & 37.6 & 14.8 & 53.0 & 33.2 & 34.1 & 13.2 & 57.0 & 28.7 & 28.3 & 14.0 \\
\hline Top 1/3 & 43.2 & 35.6 & 45.8 & 12.8 & 40.4 & 34.0 & 39.0 & 10.3 & 47.2 & 27.8 & 31.5 & 11.4 \\
\hline \multicolumn{13}{|l|}{ ESCS } \\
\hline $\begin{array}{l}\text { The } \\
\text { Lowest } \\
1 / 4\end{array}$ & 64.9 & 33.7 & 33.3 & 21.8 & 63.5 & 31.5 & 27.6 & 19.0 & 63.5 & 29.8 & 27.0 & 18.4 \\
\hline $\begin{array}{l}\text { The } \\
\text { Lower } \\
1 / 4\end{array}$ & 55.0 & 37.1 & 36.5 & 16.6 & 57.1 & 30.5 & 32.1 & 13.7 & 59.2 & 28.5 & 26.2 & 14.7 \\
\hline $\begin{array}{l}\text { The } \\
\text { Upper } \\
1 / 4\end{array}$ & 53.9 & 37.5 & 40.0 & 15.1 & 50.8 & 33.4 & 36.4 & 11.7 & 55.2 & 30.4 & 32.5 & 12.8 \\
\hline $\begin{array}{l}\text { The Top } \\
1 / 4\end{array}$ & 39.4 & 38.8 & 50.4 & 11.1 & 37.9 & 37.3 & 41.7 & 10.2 & 43.8 & 29.6 & 34.4 & 10.1 \\
\hline
\end{tabular}

Note: $1=$ one of my regular teachers; $2=$ other regular teachers in school; $3=$ specialized tutors working for a business or organization; $4=$ non-specialized tutors. Data are percentages. 
ulate that most of regular teachers still provide paid tutoring, especially in village and small town (Table 4).

\section{The Determinants of Private Tutoring}

Given participation rate of private tutoring varies across groups of students, we analyzed the determinants of receiving private tutoring by employing a two-level Bernoulli model. Table 5 displays the results.

For the individual student-level factors, students' gender, education expectation, and ability, are significantly related to the probability of receiving private tutoring. Female students are more likely to receive science and reading tutoring than male students. Education expectation can significantly positively predict the probability of receiving science and mathematics tutoring. Students' academic achievement has significantly negatively associated with the demand of private tutoring, which means Chinese students may seek tutoring for remedial purposes. It is obvious that students from prosperous families (high ESCS) have more chance to receive private tutoring than those from low economical families (low ESCS).

For the school-level factors, we constructed three models to estimate the impact of schooling quality on private tutoring. In model 1, we explored the relationship between the locations of schools with the demand of tutoring. In model 2, we estimated the impact of Education resources and teachers' quality on the demand of tutoring. In model 3, we discussed whether the quality of students can predict the probability of receiving tutoring. The results showed that: (1) Students from village schools are more likely to receive private tutoring than students from (large) city schools, and the quality of education resources, teachers, and students drives this result. With that when we put the variables of the quality of education resources, teachers, and students into the model 3 , students from large city schools become less probability to receive private tutoring than students from village schools. (2) The quality of school teachers negatively predicts the possibility of receiving tutoring. The lower proportion of teachers with master qualification the schools have, the students are more likely to receive science, mathmatics and reading tutoring. Students from schools with lower proportion of fully certified teachers have more possibility to take reading tutoring.

The urban-rural disparity does appear to affect the likelihood of participating in private tutoring, and students of village schools are more likely to receive private tutoring. The shortage of high-quality teachers in the village schools stimulates parents to purchase tutoring service to substitute for regular school education.

\section{Conclusion and Discussion}

This study applies two-level Bernoulli model to estimate the school-level determinants of private tutoring by analyzing the data of PISA 2015 conducting in four regions of China (Beijing, Shanghai, Jiangsu and Guangdong). The major findings are summarized below: 
Table 5. Results of the Two-Level Bernoulli Model.

\begin{tabular}{|c|c|c|c|c|c|c|c|c|c|}
\hline & \multicolumn{3}{|c|}{ Science } & \multicolumn{3}{|c|}{ Mathematics } & \multicolumn{3}{|c|}{ Reading } \\
\hline & M1 & M2 & M3 & M1 & M2 & M3 & M1 & M2 & M3 \\
\hline \multicolumn{10}{|c|}{ Fixed Effects } \\
\hline $\begin{array}{l}\text { Small } \\
\text { Town }\end{array}$ & $\begin{array}{l}0.04 \\
(0.34)\end{array}$ & $\begin{array}{l}0.01 \\
(0.27)\end{array}$ & $\begin{array}{l}-0.18 \\
(0.20)\end{array}$ & $\begin{array}{l}0.08 \\
(0.27)\end{array}$ & $\begin{array}{l}0.12 \\
(0.23)\end{array}$ & $\begin{array}{l}0.10 \\
(0.24)\end{array}$ & $\begin{array}{l}-0.09 \\
(0.39)\end{array}$ & $\begin{array}{l}0.01 \\
(0.32)\end{array}$ & $\begin{array}{l}0.08 \\
(0.29)\end{array}$ \\
\hline Town & $\begin{array}{l}-0.17 \\
(0.36)\end{array}$ & $\begin{array}{l}-0.24 \\
(0.32)\end{array}$ & $\begin{array}{l}-0.51^{\dagger} \\
(0.21)\end{array}$ & $\begin{array}{l}-0.19 \\
(0.28)\end{array}$ & $\begin{array}{l}-0.25 \\
(0.26)\end{array}$ & $\begin{array}{l}-0.28 \\
(0.29)\end{array}$ & $\begin{array}{l}-0.37 \\
(0.41)\end{array}$ & $\begin{array}{l}-0.27 \\
(0.37)\end{array}$ & $\begin{array}{l}-0.09 \\
(0.35)\end{array}$ \\
\hline City & $\begin{array}{l}-0.46 \\
(0.34)\end{array}$ & $\begin{array}{l}-0.56^{\dagger} \\
(0.28)\end{array}$ & $\begin{array}{l}-0.53^{\dagger} \\
(0.24)\end{array}$ & $\begin{array}{l}-0.67^{\dagger} \\
(0.27)\end{array}$ & $\begin{array}{l}-0.71^{\ddagger} \\
(0.23)\end{array}$ & $\begin{array}{l}-0.75^{\ddagger} \\
(0.26)\end{array}$ & $\begin{array}{l}-0.81^{\dagger} \\
(0.41)\end{array}$ & $\begin{array}{l}-0.75^{\dagger} \\
(0.32)\end{array}$ & $\begin{array}{l}-0.56^{*} \\
(0.32)\end{array}$ \\
\hline $\begin{array}{l}\text { Large } \\
\text { City }\end{array}$ & $\begin{array}{l}-0.44 \\
(0.33)\end{array}$ & $\begin{array}{l}-0.26 \\
(0.29)\end{array}$ & $\begin{array}{l}-0.41^{*} \\
(0.22)\end{array}$ & $\begin{array}{l}-0.30 \\
(0.26)\end{array}$ & $\begin{array}{l}-0.11 \\
(0.25)\end{array}$ & $\begin{array}{l}-0.18 \\
(0.29)\end{array}$ & $\begin{array}{l}-1.10^{\ddagger} \\
(0.39)\end{array}$ & $\begin{array}{l}-0.66^{\dagger} \\
(0.33)\end{array}$ & $\begin{array}{l}-0.31 \\
(0.36)\end{array}$ \\
\hline $\begin{array}{l}\text { Resources } \\
\text { Shortage }\end{array}$ & & $\begin{array}{l}0.08 \\
(0.08)\end{array}$ & $\begin{array}{l}0.09 \\
(0.08)\end{array}$ & & $\begin{array}{l}0.13 \\
(0.07)\end{array}$ & $\begin{array}{l}0.13^{*} \\
(0.07)\end{array}$ & & $\begin{array}{l}0.04 \\
(0.09)\end{array}$ & $\begin{array}{l}0.07 \\
(0.08)\end{array}$ \\
\hline $\begin{array}{l}\text { Staff } \\
\text { Shortage }\end{array}$ & & $\begin{array}{l}-0.08 \\
(0.07)\end{array}$ & $\begin{array}{l}-0.09 \\
(0.07)\end{array}$ & & $\begin{array}{l}-0.10 \\
(0.06)\end{array}$ & $\begin{array}{l}-0.09 \\
(0.07)\end{array}$ & & $\begin{array}{l}-0.03 \\
(0.07)\end{array}$ & $\begin{array}{l}-0.07 \\
(0.06)\end{array}$ \\
\hline PROAT5AB & & $\begin{array}{l}0.35 \\
(0.37) \\
\end{array}$ & $\begin{array}{l}0.49 \\
(0.41) \\
\end{array}$ & & $\begin{array}{l}0.36 \\
(0.38) \\
\end{array}$ & $\begin{array}{l}0.28 \\
(0.41) \\
\end{array}$ & & $\begin{array}{l}-0.06 \\
(0.44) \\
\end{array}$ & $\begin{array}{l}0.36 \\
(0.46) \\
\end{array}$ \\
\hline $\begin{array}{l}\text { PROAT5 } \\
\text { AM }\end{array}$ & & $\begin{array}{l}-2.38^{\ddagger} \\
(0.65)\end{array}$ & $\begin{array}{l}-1.75^{\dagger} \\
(0.81)\end{array}$ & & $\begin{array}{l}-1.73^{\ddagger} \\
(0.61)\end{array}$ & $\begin{array}{l}-2.13^{\ddagger} \\
(0.76)\end{array}$ & & $\begin{array}{l}-3.88^{\ddagger} \\
(0.72)\end{array}$ & $\begin{array}{l}-1.88^{\dagger} \\
(0.83)\end{array}$ \\
\hline PROATCE & & $\begin{array}{l}-2.17 \\
(1.41) \\
\end{array}$ & $\begin{array}{l}-2.08 \\
(1.39) \\
\end{array}$ & & $\begin{array}{l}-1.36 \\
(1.22) \\
\end{array}$ & $\begin{array}{l}-1.42 \\
(1.22) \\
\end{array}$ & & $\begin{array}{l}-2.09^{*} \\
(1.15)\end{array}$ & $\begin{array}{l}-1.81^{*} \\
(1.04) \\
\end{array}$ \\
\hline $\begin{array}{l}\text { Average } \\
\text { ESCS }\end{array}$ & & & $\begin{array}{l}-0.14 \\
(0.12) \\
\end{array}$ & & & $\begin{array}{l}0.09 \\
(0.11) \\
\end{array}$ & & & $\begin{array}{l}0.45^{\ddagger} \\
(0.03) \\
\end{array}$ \\
\hline $\begin{array}{l}\text { High } \\
\text { School }\end{array}$ & $\begin{array}{l}0.01 \\
(0.16) \\
\end{array}$ & $\begin{array}{l}0.01 \\
(0.16) \\
\end{array}$ & $\begin{array}{l}0.01 \\
(0.16) \\
\end{array}$ & $\begin{array}{l}-0.33^{*} \\
(0.19) \\
\end{array}$ & $\begin{array}{l}-0.33^{*} \\
(0.19) \\
\end{array}$ & $\begin{array}{l}-0.33^{*} \\
(0.19)\end{array}$ & $\begin{array}{l}-0.20 \\
(0.18) \\
\end{array}$ & $\begin{array}{l}-0.21 \\
(0.18) \\
\end{array}$ & $\begin{array}{l}-0.21 \\
(0.18) \\
\end{array}$ \\
\hline Girls & $\begin{array}{l}-0.21^{\ddagger} \\
(0.07)\end{array}$ & $\begin{array}{l}-0.21^{\ddagger} \\
(0.08)\end{array}$ & $\begin{array}{l}-0.21^{\ddagger} \\
(0.08)\end{array}$ & $\begin{array}{l}-0.06 \\
(0.08)\end{array}$ & $\begin{array}{l}-0.06 \\
(0.08)\end{array}$ & $\begin{array}{l}-0.06 \\
(0.08)\end{array}$ & $\begin{array}{l}-0.32^{\ddagger} \\
(0.08) \\
\end{array}$ & $\begin{array}{l}-0.33^{\ddagger} \\
(0.08)\end{array}$ & $\begin{array}{l}-0.33^{\ddagger} \\
(0.08) \\
\end{array}$ \\
\hline Ability & $\begin{array}{l}-0.67^{\ddagger} \\
(0.07) \\
\end{array}$ & $\begin{array}{l}-0.68^{\ddagger} \\
(0.07) \\
\end{array}$ & $\begin{array}{l}-0.68^{\ddagger} \\
(0.07) \\
\end{array}$ & $\begin{array}{l}-0.82^{\ddagger} \\
(0.07) \\
\end{array}$ & $\begin{array}{l}-0.82^{\ddagger} \\
(0.07) \\
\end{array}$ & $\begin{array}{l}-0.82^{\ddagger} \\
(0.07) \\
\end{array}$ & $\begin{array}{l}-0.89^{\ddagger} \\
(0.07)\end{array}$ & $\begin{array}{l}-0.91^{\ddagger} \\
(0.07)\end{array}$ & $\begin{array}{l}-0.91^{\ddagger} \\
(0.07) \\
\end{array}$ \\
\hline $\begin{array}{l}\text { Education } \\
\text { expectation }\end{array}$ & $\begin{array}{l}0.09^{\ddagger} \\
(0.03)\end{array}$ & $\begin{array}{l}0.10^{\ddagger} \\
(0.03)\end{array}$ & $\begin{array}{l}0.10^{\ddagger} \\
(0.03)\end{array}$ & $\begin{array}{l}0.12^{\ddagger} \\
(0.03)\end{array}$ & $\begin{array}{l}0.12^{\ddagger} \\
(0.03)\end{array}$ & $\begin{array}{l}0.12^{\ddagger} \\
(0.03)\end{array}$ & $\begin{array}{l}0.04 \\
(0.03)\end{array}$ & $\begin{array}{l}0.05 \\
(0.03)\end{array}$ & $\begin{array}{l}0.05 \\
(0.03)\end{array}$ \\
\hline ESCS & $\begin{array}{l}0.14^{\ddagger} \\
(0.05) \\
\end{array}$ & $\begin{array}{l}0.14^{\ddagger} \\
(0.05) \\
\end{array}$ & $\begin{array}{l}0.14^{\ddagger} \\
(0.05) \\
\end{array}$ & $\begin{array}{l}0.22^{\ddagger} \\
(0.05)\end{array}$ & $\begin{array}{l}0.22^{\ddagger} \\
(0.05) \\
\end{array}$ & $\begin{array}{l}0.22^{\ddagger} \\
(0.05)\end{array}$ & $\begin{array}{l}0.09^{\dagger} \\
(0.04)\end{array}$ & $\begin{array}{l}0.09^{\dagger} \\
(0.04)\end{array}$ & $\begin{array}{l}0.09^{\dagger} \\
(0.04) \\
\end{array}$ \\
\hline Inte & $\begin{array}{l}0.53^{\ddagger} \\
(0.07)\end{array}$ & $\begin{array}{l}0.50^{\ddagger} \\
(0.06)\end{array}$ & $\begin{array}{l}0.48^{\ddagger} \\
(0.06)\end{array}$ & $\begin{array}{l}1.22^{\ddagger} \\
(0.06)\end{array}$ & $\begin{array}{l}1.19^{\ddagger} \\
(0.06)\end{array}$ & $\begin{array}{l}1.21^{\ddagger} \\
(0.06)\end{array}$ & $\begin{array}{l}0.81^{\ddagger} \\
(0.08)\end{array}$ & $\begin{array}{l}0.75^{\ddagger} \\
(0.06)\end{array}$ & $\begin{array}{l}0.70^{\ddagger} \\
(0.06)\end{array}$ \\
\hline
\end{tabular}

Random Effects

\begin{tabular}{llllllllll}
\hline $\begin{array}{l}\text { Variance } \\
\text { Component }\end{array}$ & 0.37 & 0.34 & 0.34 & 0.35 & 0.33 & 0.33 & 0.53 & 0.46 & 0.41 \\
\hline$X^{2}$ & $847.3^{\ddagger}$ & $793.4^{\ddagger}$ & $787.5^{\ddagger}$ & $750.6^{\ddagger}$ & $704.1^{\ddagger}$ & $702.8^{\ddagger}$ & $1030.0^{\ddagger}$ & $906.8^{\ddagger}$ & $838.4^{\ddagger}$ \\
\hline
\end{tabular}

Note: Standard Error of Mean in parentheses; * $<0.1, t<0.05, \pm<0.01$. 
Similar to the previous studies (Zhang \& Bray, 2016; Lu, 2016; Wu, 2014), shadow education is prevalent in developed areas of China. The four regions we studied have a large scale of private tutoring, and the participation rate of private tutoring on Science, Mathematics and Chinese is $58.7 \%, 74.0 \%, 63.4 \%$, respectively.

The distribution of demand for private tutoring in the four regions of China has the following characteristics: village-city gap, interschool disparity, and regular teachers as paid tutors. In 2015, students from village schools with low quality are more likely to receive private tutoring than the students from city schools that have high quality. This finding is different from the previous studies, for example, according to Lei (2005), both the participation rates of private tutoring and tutoring expenditure in urban areas are much higher than that in rural areas in Beijing and Jiangsu. The following discussion is mainly concerned with the reason why the private tutoring is more prevalence in village than in city in 2015. First of all, when the goal in the effort to make nine-year compulsory education basically universal has been attained, the demand for school education increases in undeveloped areas, but the poor quality of regular education cannot meet students' demand, so parents have to send their children to tutoring centers. Second, the results showed that regular school teachers are mostly used tutors for the disadvantage students, while specialized tutors are most likely used for the advantage students. Perhaps regular teachers might be the best choice for disadvantage students in villages and small towns, where do not have any specialized tutoring organizations, because the fee is low and it's convenient to study in teachers' home. However, it is the low quality of public schools in villages and ineffective teaching practices in school education stimulates parents seeking private tutoring service as a "substitution" for regular school education. In fact, the phenomenon of regular teachers as paid tutors is common in China, especially in villages and small towns. Although school teachers are strictly prohibited from providing tutoring in China, it seems that this official policy has not been effectively implemented. Tutoring provided by mainstream teachers is a double-edged sword, the dark side is that we cannot prohibit the school teachers from reducing the coverage of regular lessons or revealing examination answers in tutoring class to foster demand for tutoring. What's worse, teachers might trade off their own students with other teachers to avoid being penalized by the policy.

The village-city gap and interschool disparity on the quality of regular education have significant association with the prevalence of shadow education. The results indicated that students from public schools in villages have more probability to receive private tutoring and poor quality of teachers in school lead to high demand of private tutoring in 2015. During the past ten years, the scale of shadow education in villages began to expand. We attempt to explain this change based on the theory of Supply and Demand: when compulsory education basically universally has not been attained, shadow education is more common in city. Because the quantity of public education cannot meet the demand of disadvantage families in village, they have to fight for more public education. However, advantage families in city who enjoy the quantity and quality of public education purchased tutoring service as a "complementation" to make sure they will success in education competition. When compulsory education basically universal- 
ly has been completed, shadow education becomes more popular in village and small town. For the quality of education cannot meet the demand of disadvantage families in village and small town, they have to purchase tutoring service as a "substitution" to obtain more entrance opportunity. Although families in large cities still purchase tutoring service to keep their advantage in university opportunities, the participation rate of private tutoring increased slower than that in village and small town because the quality and equity of public education has been further developed in these areas.

In overall, shadow education plays both substitutional and complementary role in school education, that the growth of shadow education is in accompany with the low quality of school education in village and small town, where families purchase shadow education as a "substitution" to obtain more entrance opportunity when the quality of school education cannot meet their demand. The growth of shadow education develops with the high quality of school education in city, where families purchase shadow education as a "complementation" to make sure they keep their advantage in education competition. However, shadow education is mostly provided by regular teachers of public schools in village and small town, and in city, most of the students choose specialized tutors.

It's necessary to re-examine the problem of school education according to the development of shadow education. First, there is still urban-rural disparity in educational quality. To decrease the participation probability of private tutoring, the government should increase teacher quality of regular education, with the increasing of the quality of education resources and improving of the infrastructure building. Second, the phenomenon of regular teachers as tutors is common, especially in undeveloped areas, such as villages and small towns. "Why do school teachers provide paid tutoring? Do the students participate in tutoring provided by teachers on their own? Are there any "corruption" behavior for school teachers to attract more students to participate in their tutoring class?" Schools and educational institution should pay more attention to these problems. Third, no matter the "substitutional" role of shadow education in village, or the "complementary" role in city, shadow education seems to replicate educational inequality outside school, which has negative impact on the quality and equity of regular education. Of course, it remains to be verified whether the results of the relationship between regular education and shadow education based on the data of these four regions are applicable to other provinces and cities. 


\section{References}

Baker, D., LeTendre, G. K. (2005) National differences, global similarities: World culture and the future of schooling. Stanford University Press.

Bray, M. (1999) The shadow education system: private tutoring and its implications for planners. Fundamentals of Educational Planning Series; Number 61.

Bray, M., Zhan, S., et al. (2014) Differentiated demand for private supplementary tutoring: Patterns and implications in Hong Kong secondary education. Econ Edu Rev, 38: 2437.

Byun, S. Y., and Park, H. (2012) The academic success of East Asian American youth the role of shadow education. Sociol Edu, 85(1):40-60.

Choi, Y., \& Park, H. (2016) shadow education and educational inequality in south korea: examining effect heterogeneity of shadow education on middle school seniors' achievement test scores. Res Soc Stratif Mob, 44:22-32.

Coleman, J. S., et al. (1996) Equality of educational opportunity.

Dang H. A., Rogers F. H. (2008) The growing phenomenon of private tutoring: Does it deepen human capital, widen inequalities, or waste resources? World Bank Res Obs, 23(2):161-200.

Dang, H. A. (2007) The determinants and impact of private tutoring classes in Vietnam. Econ Edu Rev, 26(6): 683-698.

Hanushek, E. A. (1986) The economics of schooling: Production and efficiency in public schools. J Econ Lit, 24(3):1141-1177.

Ho, E. S. C. (2011). Shadow education in Asian society from an international perspective. Analysing the quality and equality of educational systems from $n$ international perspective insights from PISA (pp: 271-

296).Educational Science Publishing House.

Kim, S., Lee, J. H. (2010) Private tutoring and demand for education in South Korea. Econ Dev Cult Chang, 58(2):259-296.

Lei, W. P. (2005) Expenditure on private tutoring for senior secondary students: determi- nants and policy implications. Edu Econ, (1):39-42.

Li, J.L., Hu, Y. M. (2017) Who can benefit from shadow education and its implication for education inequality. Edu Econ, (2):87-101.

Lu, K. (2016) Investigation on private tutoring of primary and secondary school students in Beijing. Shanghai Res Edu, (5):37-40.

Park, H., et al. (2016) Learning beyond the school walls: trends and implications. Ann Rev Sociol, 42:231-252.

Popa, S., Acedo, C. (2006) Redefining professionalism: Romanian secondary education teachers and the private tutoring system. Int J Edu Dev, 26(1):98-110.

Shavelson, R., Baxter, G. (1992) On measuring the quality of mathematics and science education: achievement indicators. Measuring the Quality of Education; 35-54.

Southgate, D. E. (2013) Family capital: A determinant of supplementary education in 17 nations. Out of the Shadows. Glob Intensif Suppl Edu, 22:245-258.

Stevenson, D., and Baker, D. (1992) Shadow Education and Allocation in Regular schooling: Transition to University in Japan. Am J Sociol, 97(6):1639-1657.

Tsang, M. C., Ding, X. H., \& Shen, H. (2010). Urban- rural disparities in private tutoring of lower-secondary students. Edu Econ, (2):711.

Wu, K. (2010) Three levels of educational opportunity equity. Chin Edu Newspap, 201005-04(004).

$\mathrm{Wu}, \mathrm{Y}$. (2014) The private tutoring in middle school schools from the perspective of education equality: A case study in Guangzhou. Edu Res, (8):75-84.

Xue, H. P. (2015). From school education to shadow education: Education competition and social reproduction. Peking Univ EduRev, 13(3):47-69.

Xue, H. P., \& Ding, X. H. (2008). An empirical study on private tutoring for students in urban China. Econ Edu Res (Beida), 6(1):1-14.

Zhang, W., Bray, M. (2016) Microneoliberalism in China: public-private inter- 
actions at the confluence of mainstream and shadow education. J Edu Pol, 32(1):63-81.
Zhu, X. (2013) Shadow education cultural capital theory under globalization of education. Tsinghua J Edu, 4:51-55.

Received: 22 October 2019

Revised: 11 December 2019

Accepted: 20 December 2019

The Chinese version of this article has been published in Beijing Social Sciences, 2019; 5: 57-68. The English version has been authorized for being publication in BECE by the author(s) and the Chinese journal.

李佳丽. “替代” 还是 “补充”: 从影子教育发展审视学校教育质量-基于 PISA2015 中国四省市 数据的分析. 北京社会科学, 2019; 5: 57-68. 